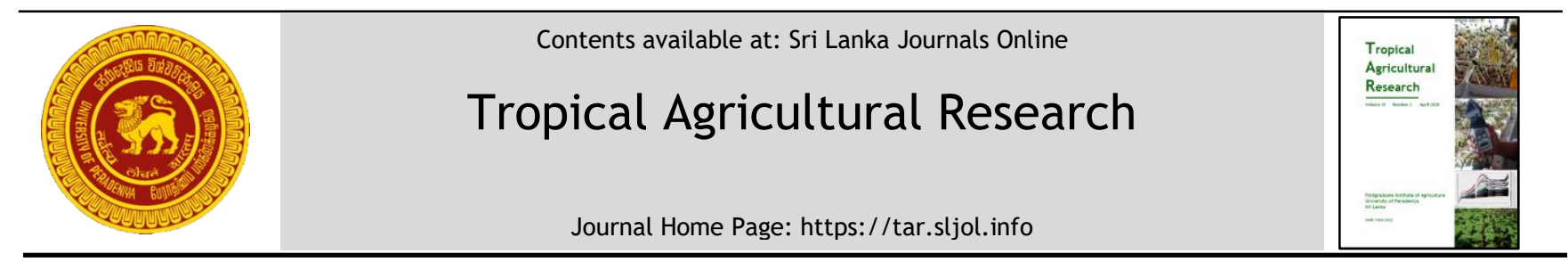

\title{
Evaluation of Energy Balance in Tropical and Temperate Crossbred Dairy Cows at Post-Partum Transition Stage: A Case Study
}

\author{
K.K.T.N. Ranaweera ${ }^{1}$, M.B.P.K. Mahipala ${ }^{2 *}$ and W.M.P.B. Weerasinghe ${ }^{3}$ \\ ${ }_{1}^{1}$ Postgraduate Institute of Agriculture, University of Peradeniya, Peradeniya, Sri Lanka \\ ${ }^{2}$ Department of Animal Science, Faculty of Agriculture, University of Peradeniya, Sri Lanka \\ ${ }^{3}$ Veterinary Research Institute, Gannoruwa, Peradeniya, Sri Lanka
}

\section{ARTICLE INFO}

\section{Article history:}

Received: 22 August 2019

Accepted: 23 October 2019

Available online: 1 April 2020

\section{Keywords:}

Metabolic profile

Nutritional state

Serum NEFA, BHBA and Urea

\section{Citation:}

Ranaweera, K.K.T.N., Mahipala, M.B.P.K. and Weerasinghe, W.M.P.B.. (2020). Evaluation of Energy Balance in Tropical and Temperate Crossbred Dairy Cows at Post-Partum Transition Stage: A Case Study. Tropical Agricultural Research, 31(2): 12-20.

DOI: http://doi.org/10.4038/tar.v31i2.8363

Ranaweera, K.K.T.N. https://orcid.org/0000-0001-8117-2522

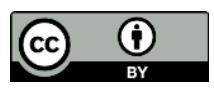

\footnotetext{
*Corresponding author: pmahi@pdn.ac.lk
}

\begin{abstract}
Objective of the present study was to assess the energy balance of tropical (Sahiwal x Jersey) and temperate (Friesian $\mathrm{x}$ Jersey) crossbred dairy cows in Sri Lanka using serum metabolic profile. The study consisted of tropical and temperate crossbred dairy cows which were at post-partum transition stage, and were from two medium-scale farms in low country dry zone, and mid country intermediate zone, respectively. Each cow was bled (0800 hours) on the day of data collection and serum metabolic profile was assessed. Milk production, body weight and body condition score (BCS) of cows were recorded whereas, dry matter, crude protein and metabolizable energy contents of the mixed rations fed to cows in both farms were analysed. Results revealed that, serum non-esterified fatty acids (NEFA), urea and calcium contents were significantly $(\mathrm{P}<0.05)$ high, serum betahydroxybutyric acid (BHBA) content was significantly $(\mathrm{P}<0.05)$ low in temperate crossbred cows compared to those of tropical crossbred cows at post-partum transition stage. The serum BHBA content $(1.32 \pm 0.11 \mathrm{mmol} / \mathrm{L})$ of tropical crossbred cows, and NEFA $(0.62 \pm 0.15 \mathrm{mmol} / \mathrm{L})$ and urea $(30.09 \pm 2.60 \mathrm{mg} / \mathrm{dL})$ content of temperate crossbred cows at post-partum transition stage exceeded the upper critical limit of the reference range proposed for the determination of NEB. The recorded inferior BCS of both tropical $(2.9 \pm 0.6)$ and temperate $(2.5 \pm 0.2)$ crossbred dairy cows further confirmed their poor energy balance under the present feeding system. It was concluded that, both tropical and temperate crossbred dairy cows at post-partum transition stage suffer from negative energy balance under the current feeding system in the two medium-scale farms studied. The BHBA level was suggested as more appropriate indicator to assess the energy balance in dairy cows, managed under free-stall system. Adoption of energy-dense feeding programs and overcoming energy deficiency are suggested to optimize the productivity of dairy cattle in low-country, dry-zone and mid-country intermediate-zone.
\end{abstract}




\section{INTRODUCTION}

Fifty-six percent of Sri Lankan cattle population is found in the dry-zone. They are either tropical crossbred or non-descriptive cattle. Large proportion (75\%) of the genetically improved cattle (i.e. pure temperate or their crosses) is managed in the mid country and up country farms. Crossbred cows managed in these regions play a significant role in domestic dairy industry (Ibrahim et al., 1999). Despite great genetic potential for milk production, productivity of crossbred cows currently lies below 10 L/cow/day in both dry zone and mid country areas (Subasinghe and Abeygunawardena, 2011). Appropriate nutritional status is one of the key factors leading to high productivity particularly in improved dairy cattle. Hence, assessment of nutritional status of dairy cows is of utmost importance in dairy cattle husbandry. Investigation of serum metabolic profile is a novel technique used to assess nutritional status of dairy cows in developed countries (Shapiro and Lusis, 2015). A precise nutritional assessment in dairy cows could be made by combining blood metabolic profile and body condition score (BCS) and nutritive value of feed (Kida, 2003).

Period between three weeks pre-partum and three weeks post-partum (transition period) is considered as a critical period in the sense of nutritional demand and disease susceptibility in dairy cows (Bell, 1995; Drackley, 1999; Leblanc, 2010). Negative energy balance (NEB) caused by severe increment in nutrient demand for milk production coupled with greater decrease (i.e. about $30 \%$ ) in dry matter intake (DMI) is the biggest challenge faced by transition cows (Goff and Horst, 1997). Calving stress and endocrine changes that occur during early stages of the lactation are two main reasons for the reduction of DMI (Leblanc, 2010). Hence, nutritional assessment of dairy cows at transition stage is beneficial to propose better feeding strategy which ensures successful subsequent lactation yield. Such assessment has never been carried out in Sri Lanka. Therefore, the present study was designed to assess the energy balance using serum metabolic profile in temperate and tropical crossbred dairy cows at post-partum transition stage in two selected dairy cattle farms each in mid country intermediate zone (MCIZ), and low country dry zone (LCDZ) of Sri Lanka.

\section{MATERIALS AND METHODS}

\section{Experimental Sites and Animals}

The sampling protocol suggested by PennState University Extension (2017) was followed. Fifteen tropical crossbred (Sahiwal x Jersey) dairy cows managed in a LCDZ farm (Haifah farm, Walikanda, $7^{\circ} 53^{\prime} \mathrm{N}$ and $81^{\circ} 09^{\prime} \mathrm{E}$ ) and 15 temperate crossbred (Friesian x Jersey) dairy cows managed in a MCIZ farm (Sri Lak farm, Nawalapitiya, $7^{\circ} 04^{\prime} \mathrm{N}$ and $80^{\circ} 56^{\prime} \mathrm{E}$ ) were selected for the study. All 30 cows were multiparous and were at post-partum transition stage. They were fed ad-libitum with a mixed ration twice a day after morning and evening milking. Table 1 presents the details of animals and feeds used in the study.

\section{Data collection:}

On the day of data collection, morning and evening milk production, body weight and body condition score (1-5 scale as described by Ferguson et al., 1994) of cows were recorded.

Representative ration samples (i.e. 500g) were collected from both morning and evening meals on the previous day of blood sample collection, and stored at $-20^{\circ} \mathrm{C}$. They were allowed to thaw at room temperature, dried at $105^{\circ} \mathrm{C}$ and ground using a hammer mill to pass through a $0.5 \mathrm{~mm}$ sieve (Glen Creston Ltd., United Kingdom). Morning and evening feed samples were then mixed to form composite samples, and stored in clean, labeled bottles until analyzed for dry matter (AOAC 934.01), crude protein (AOAC 984.13), and gross energy content (using a bomb calorimeter; Model No: A1435DDEE, Parr Instruments, Illinois, USA). 
Table 1: Ration composition, nutritive value of feed, nutrient requirement and milk production of tropical and temperate crossbred dairy cows at post-partum transition stage.

\begin{tabular}{lcc}
\hline & $\begin{array}{c}\text { Tropical crossbred } \\
\text { cows }\end{array}$ & $\begin{array}{c}\text { Temperate crossbred } \\
\text { cows }\end{array}$ \\
\hline Ration composition (g/kg Dry matter) & & 435.5 \\
- Grass (Panicum maximum) & 568.3 & 208.9 \\
- Coconut cake & - & - \\
- Maize (Zea mays) grain powder & 6.6 & 120.7 \\
- Dhal dust & 194.8 & 210.0 \\
- Rice polish & 183.0 & 11.5 \\
- Beer pulp & - & - \\
- Molasses & 32.5 & 6.6 \\
- Mineral mixture & - & 6.6 \\
- Salt & - & - \\
- Di-calcium phosphate & 14.8 & 35.3 \\
Nutritive value & & 13.4 \\
- DM (\%) & 32.6 & 8.3 \\
- CP (\%) & 10.5 & \\
- ME (MJ/kg DM) & 8.1 & 1.2 \\
Nutrient requirement* & & 94.4 \\
- CP (kg/cow/day) & 1.2 & 10.5 \\
- ME (MJ/cow/day) & 98.0 & \\
Milk production (L/cow/day) & 8.5 & \\
\hline * Nutrient requirements were estimated considering respective body weight (Table 3) and \\
production of tropical and temperate crossbred cows as recommended by National Research \\
Council (2001). & & \\
& &
\end{tabular}

\section{Analysis of Blood Metabolic Profile:}

Blood samples were drawn through jugular vein or coccygeal vein of each cow, into blood collecting tubes without EDTA, at 0800 hours, on the day of data collection. They were allowed to clot at room temperature for 3 hours before centrifuging at $2000 \mathrm{Xg}$ for 10 minutes. Serum was then separated and stored at $-20^{\circ} \mathrm{C}$ until metabolic profile was determined. The serum non-esterified fatty acids (NEFA), beta-hydroxybutyric acid (BHBA), urea, albumin, calcium and phosphorous contents were determined using Randox serum test kits (Randox Laboratory Limited, United Kingdom) and auto analyzer (i.e. 3000
Evolution ${ }^{\circledR}$ Auto Analyzer, Biochemical System International, Arezzo, Italy).

\section{Data Analysis:}

Pooled t-test was performed to compare serum metabolic profiles of tropical and temperate crossbred dairy cows at postpartum transition period using version 9.2 of SAS software (SAS Institute Inc., 2003). Means of metabolite contents were compared with respective upper and lower critical limits of the reference ranges proposed to assess the state of energy balance for tropical and temperate dairy cows as given in Table 2 . 
Table 2: Reference range of serum metabolites of temperate and tropical crossbred dairy cows for identification of status of negative energy balance

\begin{tabular}{lcccc}
\hline Metabolite & \multicolumn{2}{c}{$\begin{array}{c}\text { Critical limits for } \\
\text { tropical crossbred cows }\end{array}$} & \multicolumn{2}{c}{$\begin{array}{c}\text { Critical limits for } \\
\text { temperate crossbred cows }\end{array}$} \\
\cline { 2 - 5 } & Lower limit & Upper limit & Lower limit & Upper limit \\
\hline & & & & \\
NEFA (mmol/L) & 0.01 & $0.52^{1}$ & 0.01 & $0.52^{1}$ \\
BHBA (mmol/L) & 0.22 & $1.18^{2}$ & 0.30 & $1.50^{1}$ \\
Albumin (g/dL) & 2.70 & $4.70^{3}$ & 2.80 & $3.90^{4}$ \\
Urea (mg/dL) & 5.00 & $27.00^{3}$ & 5.00 & $27.00^{3}$ \\
Ca (mg/L) & 6.56 & $10.44^{2}$ & 7.00 & $11.00^{5}$ \\
P (mg/L) & 4.50 & $8.00^{1}$ & 4.30 & $8.00^{3}$ \\
\hline 1 PennState Extension, 2017; ${ }^{2}$ Quiroz-Rocha et al., $2009 ;{ }^{3}$ Lager and Jordan, 2012; ${ }^{4}$ Kahn and \\
Line, 2011; ${ }^{5}$ Puls, 1989.
\end{tabular}

\section{RESULTS AND DISCUSSION}

Serum NEFA, albumin, urea, calcium and phosphorous contents of tropical crossbred dairy cows were found to be within the respective reference ranges. However, their serum BHBA content was greater than the upper critical limit of the reference range (Figures 1 - 3). The temperate crossbred cows recorded serum BHBA, albumin, calcium and phosphorous contents within the respective reference range while serum NEFA and urea contents exceeded the upper critical limit of respective reference ranges.

Although the nutrient demand of dairy cows for milk production is enhanced intensely with the onset of lactation, the DMI increases slowly causing them to mobilize body reserves (Reist et al., 2002). Hence, triacylglycerols of the adipose tissues are mobilized as NEFA to meet the energy demand particularly during their postpartum transition stage. Elevated levels of serum NEFA indicates NEB in dairy cows at transition period (Chilliard et al., 2000). A similar situation was observed only among the temperate crossbred cows at postpartum transition stage in the present study (Figure 1). Therefore, the findings provide evidence that the temperate crossbred cows experience NEB during the post-partum transition stage under the present management in the MCIZ. Additionally, the serum NEFA content of temperate crossbred cows at post-partum transition stage was significantly $(\mathrm{P}<0.05)$ greater than that of tropical crossbred cows. Contrary, the serum BHBA content of temperate crossbred cows at post-partum transition stage was significantly $(\mathrm{P}<0.05)$ lower than that of tropical crossbred cows. Tropical and temperate crossbred cows of the present study were managed in free-stall and tiestall systems, respectively. Therefore, it is obvious that the tropical cows were more active compared to temperate crossbred cows. Muscle activity of active animals leads to a comparatively high blood flow to muscles and uptake of NEFA as an energy source for muscle tissues compared to less active animals. Hence, oxidation of NEFA for energy is more in active animals (van Hall, 2015). Yet, NEFA is partially oxidized and converted into ketone bodies such as BHBA and acetoacetate due to lack of oxaloacetate, when animals experience NEB (McDonald et al., 2011). Hence, active cows oxidize more serum NEFA and record greater serum BHBA than their counterparts when experience NEB. Adewuyi et al., (2006) also reported that walking activity cause to decrease the serum NEFA content. Therefore, despite the low level of NEFA (Figure 1) the tropical crossbred cows also experience NEB during the post-partum transition stage under the current free-stall management in the LCDZ. Further, the findings suggest that the level of BHBA is a better indicator than NEFA to assess the state of energy balance of cows managed under free-stall system. 


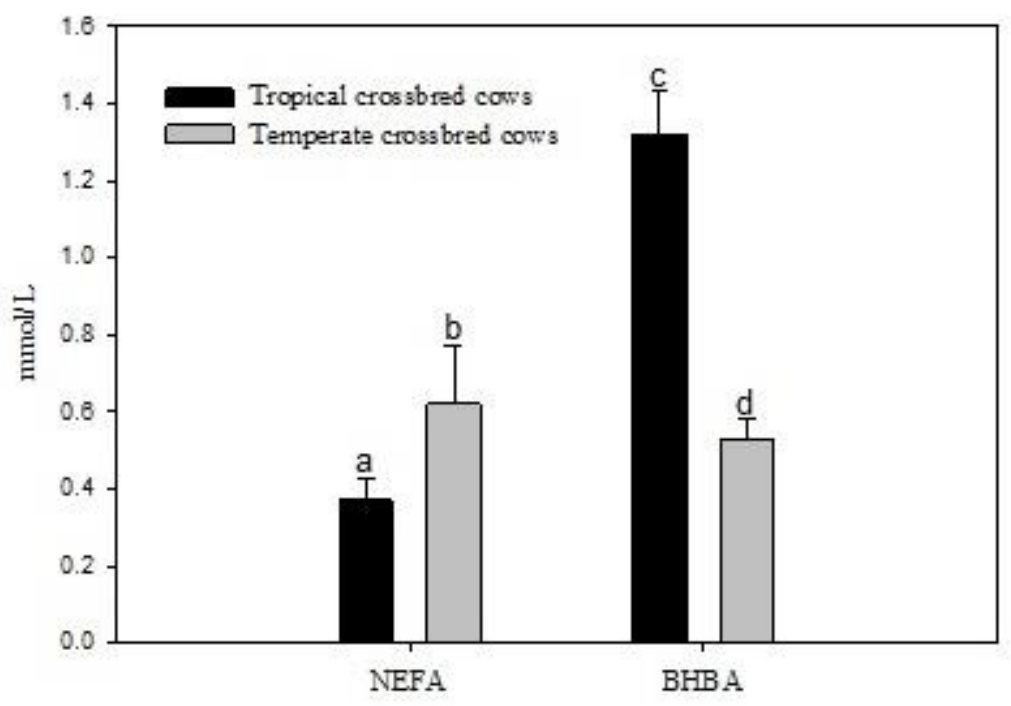

Figure 1: Serum NEFA and BHBA contents $f$ tropical and temperate crossbred dairy cows at post-partum transition stage

Serum calcium and urea contents of tropical crossbred cows were significantly $(\mathrm{P}<0.05)$ lower than those of temperate crossbred cows at the post-partum transition stage (Figures 2 and 3). Garcia et al. (2017) and Sosa et al. (2010) have also reported greater serum calcium and urea contents in high producing cows than in low producing cows.
The present study recorded high milk production in temperate crossbred cows (10.5 L/cow/day) compared to tropical crossbred cows (8.5 L/cow/day). Prisacaru (2014) confirmed that there is a variation in the serum calcium content among different breeds (Fleckvieh, Pinzgauer, Black Spotted Romanian) of cattle.

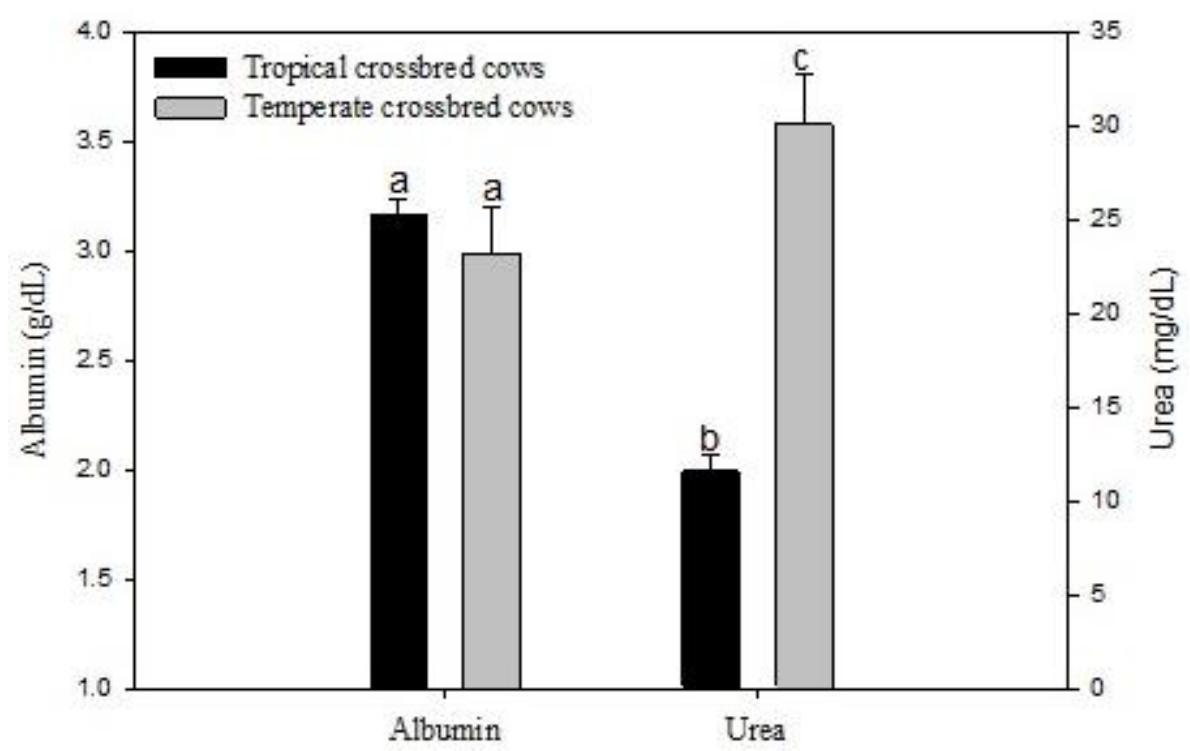

Figure 2: Serum albumin and urea contents of tropical and temperate crossbred dairy cows at post-partum transition stage 


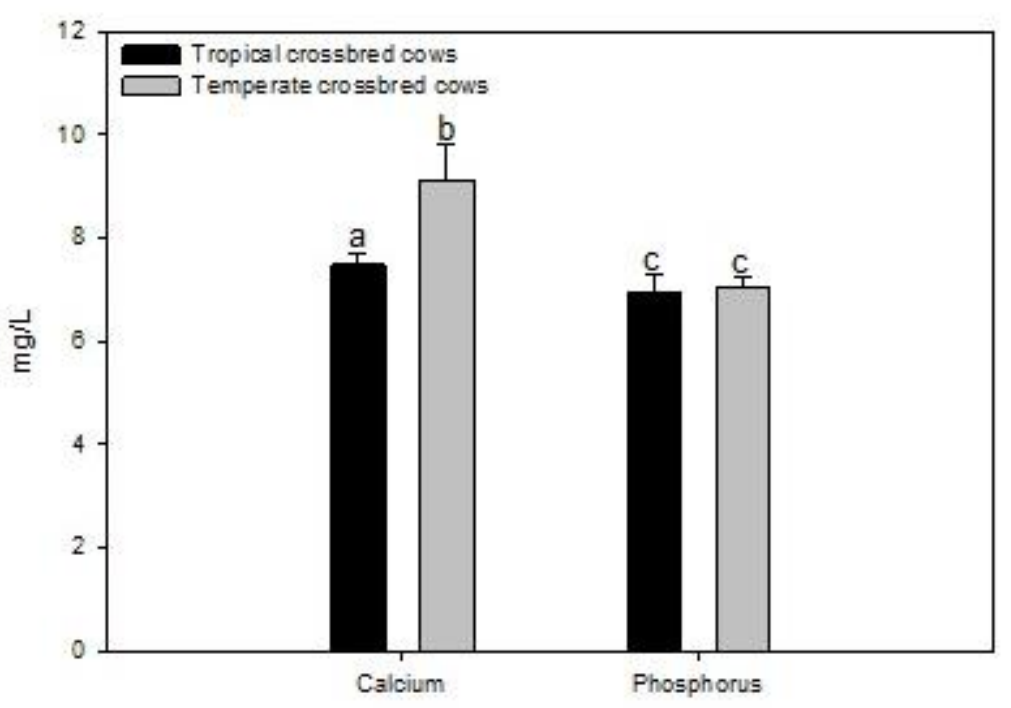

Figure 3: Serum calcium and phosphorous contents of tropical and temperate crossbred dairy cows at post-partum transition stage

Hence, it can be suggested that owing to the differences in yield and genetic makeup, the serum calcium content between tropical and temperate crossbred dairy cows at postpartum transition stage varies. Hammond (1997) reported that dairy cow rations with adequate protein with less dietary energy increased serum urea content due to inefficient utilization of ammonia production in the rumen. Thus, it can be argued that significantly $(\mathrm{P}<0.05)$ greater serum urea recorded (i.e. exceeding the upper critical limit of reference range) among the temperate crossbred cows is an indication of feeding of energy deficient diet.

Though the BCS of tropical crossbred cows at post-partum transition stage was significantly $(\mathrm{P}<0.05)$ greater than that of their counterparts, both groups reported BSC below 3.0 (Table 3) which is a reflection of poor nutritional status of post-partum dairy cows. Further, lower body condition at calving may indicate poor productive and reproductive performances in the subsequent lactation (Roche et al., 2009). Thus, the productive and reproductive performance of tropical and temperate crossbred dairy cows will be greatly lower than their genetic potential under the present management of the two respective farms in LCDZ and MCIZ.

The $\mathrm{CP}$ and ME requirements for tropical and temperate cows with $408.6 \mathrm{~kg}$ and 356.5 kg body weight (Table 3) producing 8.5 L/day and 10.5 L/day of milk (Table 1), respectively were estimated according to recommendations of NRC (2001). As presented in Table 1, composition of the rations offered for dairy cows in the present meets the respective nutritional requirements despite that both groups of cows experienced NEB during post-partum transition. Therefore, regardless of nutritive value of the rations, low nutrient intake may have created energy deficiency in both tropical and temperate crossbred dairy cows studied. Several studies reported that the DMI of dairy cows at transition was retarded by multiple stresses caused by numerous metabolic and endocrine changes occurs during the period (Zamet et al., 1979; Lean et al., 1994; Mendelez, 2008; Gross et al., 2013). Therefore, as reported by Rabelo et al. (2003), feeding the crossbred transition cows with energy dense rations will result more energy intake and thereby high milk production in the subsequent lactation. 
Table 3: Body weight and body condition score (BCS) of tropical and temperate crossbred dairy cows at post-partum transition stage

\begin{tabular}{lrllrll}
\hline Parameter & \multicolumn{7}{c}{ Tropical crossbred cows $^{\dagger}$} & Temperate crossbred cows \\
\hline & & & & & & \\
Body weight (kg) & 408.4 & \pm & $6.5^{\mathrm{a}}$ & 356.5 & \pm & $13.3^{\mathrm{b}}$ \\
BCS & 2.9 & \pm & $0.6^{\mathrm{a}}$ & 2.5 & \pm & $0.2^{\mathrm{b}}$ \\
\hline
\end{tabular}

†, Mean \pm SE

Means followed by different superscripts within a row are significantly different $(P<0.05)$.

\section{CONCLUSIONS}

It can be concluded that both tropical and temperate crossbred dairy cows at postpartum transition stage suffer from NEB under the tie-stall and free-stall feeding systems currently practiced in LCDZ and MCIZ, respectively. The level of serum BHBA is an appropriate indicator to assess the state of energy balance of dairy cows, managed under free-stall system. Poor DMI could be suggested as one of the main causes for the NEB status in both tropical and temperate crossbred dairy cows in LCDZ and MCIZ. Thus, the condition could be overcome by feeding the post-partum dairy cows with energy dense rations.

\section{ACKNOWLEDGEMENTS}

This work was facilitated by the National Research Council, Sri Lanka (Grant No. NRC TO 14-10) and Research Facilitation Fund of Post Graduate Institute of Agriculture, University of Peradeniya. Authors acknowledge assistance of Prof. M.P.B. Wijayagunawardena, Mrs. H.M.G.P. Herath, Prof. Basil Alexander, Dr. K. Nizananthan Dr. Devinda Wickramasinghe and Mr. Tharindu Sampath. Mr. Bazir Mohommad, Proprietor of Haifah Farm and Mr. Buddhika Gunathilake, Managing Director of Sri Lak farm are acknowledged for facilitating to conduct the research at the farms.

\section{REFERENCES}

Adewuyi, A.A., Roelofs, J.B., Gruys, E., Toussaint, M.J.M. and van Eerdenburg F.J.C.M. (2006). Relationship of plasma non-esterified fatty acids and walking activity in postpartum dairy cows. Journal of Dairy Science. 89 (8), 2977-2979.
Bell, A.W. (1995). Regulation of organic nutrient metabolism during transition from late pregnancy to early lactation. Journal of Animal Science. 73, 2804-2819.

Chilliard, Y., Ferlay, A., Faulconnier, Y., Bonnet, M., Rouel, J., \& Bocquier, F. (2000). Adipose tissue metabolism and its role in adaptations to undernutrition in ruminants. Proceedings of the Nutrition Society, 59(1), 127-134. doi:10.1017/S002966510000015X

Drackley, J.K. (1999). Biology of dairy cows during the transition period: the final frontier. Journal of Dairy Science. 82(11), 2259-2273.

Ferguson, J.D., Galligan, D.T. and Thomsen, N. (1994). Principal descriptors of body condition score in Holstein cows. Journal of Dairy Science. 77, 2695-2703.

Garcia, C.A.C., Prado, F.M.G., Galicia, L.L. and Borderas, T.F. (2017). Reference values for biochemical analytes in Mexican Dairy Farms: Interactions and adjustments between production groups. Arquivo Brasileiro de Medicina Veterinária E Zootecnia. Mexico: Escola de Veterinária - Universidade Federal de Minas Gerais. 69 (2), 445-456.

Goff, J.P. and Horst, R.L. (1997). Physiological changes at parturition and their relationship to metabolic disorders. Journal of Dairy Science. 80(7), 1260-1268.

Gross, J.J., Schwarz, F.J., Eder, K., van Dorland, H.A. and Bruckmaier, R.M. (2013). Liver fat content and lipid metabolism in dairy cows during early lactation and during a midlactation feed restriction. Journal of Dairy Science. 96 (8), 5008-5017.

Hammond, A.C. (1997). Update on BUN and MUN as a guide for protein supplementation in 
cattle. US Department of Agriculture, Agricultural Research Service Subtropical Agricultural Research Station Brooksville, Florida.

Ibrahim, M.N.M., Staal, S.J., Daniel S.L.A. and Thorpe, W. (1999). 1 Appraisal of the Sri Lanka dairy sector, Volume 1: Dept. of Animal Science, University of Peradeniya; International Livestock Research Institute, Ministry of Livestock Development and Estate Infrastructure. Colombo.

Kahn, C.M. and Line, S. (2011). Merck Veterinary Manual. Whitehouse Station, N.J: Merck \& Co. 10th ed, pp.2.

Kida, K., (2003). Relationships of metabolic profiles to milk production and feeding in dairy cows. The Journal of veterinary medical science / The Japanese Society of Veterinary Science. 65(6), 671-7.

Lager, K., Jordan, E. In: Jordan E (2012) The metabolic profile for the modern transition dairy cow; Proceedings of the mid-south ruminant nutrition conference; 2012; Grapevine, TX, USA: Texas A and M University, 9-16

Lean, I.J., Bruss, M.L., Troutt, H.F., Galland, J.C., Farver, T.B., Rostami, J., Holmberg, C.A. and Weaver, L.D. (1994). Bovine ketosis and somatotrophin: Risk factors for ketosis and effects of ketosis on health and production. Research in Veterinary Science. 57 (2), 200209.

Leblanc, S. (2010). Monitoring metabolic health of dairy cattle in the transition period. Journal of Reproduction and Development. 56, 29-35.

McDonald, P., Edwards, R., Greenhalgh, J.F.D., Morgan, C., Sinclair, L. and Wilkinson. R.G. (2011). Animal Nutrition. $7^{\text {th }}$ ed. London: Pearson.

Mendelez, P. (2008). Nutritional management of the transition period to optimize fertility in dairy cattle. Veterinary Practitioner. 9, 83-88.

National Research Council. 2001. Nutrient Requirements of Dairy Cattle: Seventh Revised Edition, 2001. Washington, DC: The National Academies Press.
PennState University Extension. (2017). Metabolic profiling of transition cows: Can we predict impending problems? [online] [Accessed on 04.01.2017]. Available at http://extension.psu.edu/animals/health/ metabolicprofiling/bibliography/metabolic profiling-of- transition-cows- can-we- predictimpending- problems

Prisacaru, A.E. (2014). Effects of age, sex and breed on biochemical blood parameters of cCattle at slaughterhouse. Lucrări Ştiinţifice Seria Zootehnie. 62, 164-168.

Puls, R. (1989). Mineral levels in animal health: Diagnostic data. In: Minerals in Animal Nutrition. (2nd Ed.). Sherpa Int., Clearbrook, $\mathrm{BC}$, Canada.

Quiroz Rocha, G.F., LeBlanc, S.J., Duffield, T.F., Wood, D., Leslie, K.E. and Jacobs, R.M. (2009). Reference limits for biochemical and hematological analytes of dairy cows one week before and one week after parturition. Canadian Veterinary Journal. 50 (4): 383-88.

Rabelo, E., Rezende, R.L., Bertics, S.J. and Grummer, R.R. (2003). Effects of transition diets varying in dietary energy density on lactation performance and ruminal parameters of dairy cows. Journal of Dairy Science. 86(3),916-25.

Reist, M., Erdin, D., von Euw, D., Tschuemperlin, K., Leuenberger, H., Chilliard, Y., Hammon, H.M., Morel, C., Philipona, C., Zbinden, Y., Kuenzi, N. and Blum, J.W. (2002). Estimation of energy balance at the individual and herd level using blood and milk traits in high-yielding dairy cows. Journal of Dairy Science 85 (12). Elsevier: 3314-27.

Roche J.R., Friggens N.C., Kay J.K., Fisher M.W., Stafford K.J. and Berry D.P. (2009). Invited review: Body condition score and its association with dairy cow productivity, health, and welfare. Journal of Dairy Science. 92(12), 5769-5801.

SAS 9.2. (2003). SAS Institute Inc., Cary, North Carolina, USA.

Shapiro, J. and Lusis, P. (2015). AHL LabNote, Animal Health Laboratory, Laboratory Services Division, University of Guelph. https://doi.org/10.17226/9825. 
Sosa, I., Leyton, L. and Corea, E., (2010). Correlation between milk and blood urea nitrogen in high and low yielding dairy cows. In N.E. Odongo, M. Garcia, and G.J. Viljoen, eds. Sustainable Improvement of Animal Production and Health. Rome: Food and Agriculture Organization of the United Nations, pp. 79-82.

Subasinghe, D.H.A. and Abeygunawardena, H. (2011). Dairy industry in Sri Lanka - Part I. Sri Lanka Veterinary Journal. 58(B), 29-34.
Van Hall, G. (2015). The physiological regulation of skeletal muscle fatty acid supply and oxidation during moderate-intensity exercise. Sports Medicine. 45(1), 23-32.

Zamet, C.N., Colenbrander, V.F., Callahan, C.J., Chew, B.P., Erb, R.E. and Moeller, N.J. (1979). Variables associated with peripartum traits in dairy cows. I. Effect of dietary forages and disorders on voluntary intake of feed, body weight and milk yield. Theriogenology. 11 (3), 229-44. 